полученных результатов сделаны выводы о онтогенетической структуре ценопопуляций P. aviculare в условиях исследуемого района.

Ключевые слова: Кролевецко-Глуховский геоботанический район, Polygonum aviculare L., онтогенетические спектры, онтогенетическая структура, фитопопуляции.

Zubtsova Inna. Ontogenetic Structure of Cenopopulations Polygonum Aviculare L. Under the Conditions of Krolevetsky-Hlukhivsky Geobotanic Region. The article presents ontogenetic structure of cenopopulations Polygonum aviculare L. on the meadows of Krolevetsky-Hlukhivsky geobotanic region. The index of age according to A. A. Uranov $(\Delta)$ and index of efficiency according to L. V. Zhyvotkovsky $(\omega)$ were calculated. Affiliation of each studied cenopopulations to a certain category is determined, according to classifications of T. O. Rabotnov (invasive, normal, regressive), L. V. Zhyvotkovsky (young, transient, maturing, mature, ageing, old). Ontogenetic spectra of cenopopulations $P$. aviculare were constructed and analyzed in the aspect of their belonging to one of the types: left-side, centered, right-side. Proportion of plants of different ontogenic states in six populations $P$. aviculare was determined. On the basis of the received results there were made conclusions on the ontogenetic structure of cenopopulations $P$. aviculare under the conditions of the studied region.

Key words: Krolevetsky-Hlukhivsky geobotanic region, polygonum aviculare 1., ontogenetic spectrum, ontogenetic structure, phytopopulation.

Стаття надійшла до редколегії 12.09.2016 р.

УДК 634.7:631.27:631.53:582:001.4

Олег Василюк, Світлана Свсікова

\title{
Оцінка успішності акліматизації, характеристика біоекологічних особливостей малопоширених плодових та ягідних видів на базі Кременецького ботанічного саду
}

У статті наведено результати аналізу біоекологічної структури дендрофлори. Установлено оцінку результатів успішності акліматизації на прикладі колекції малопоширених плодових і ягідних видів у Кременецькому ботанічному саду за показниками росту, генеративного розвитку та впливу екологічних факторів.

Ключові слова: колекція, екоморфа, життєва форма, ступінь акліматизації, зимостійкість, генеративний розвиток.

Постановка наукової проблеми та її значення. Вивчення, упровадження малопоширених плодових і ягідних рослин у різноманіття Кременецького горбогір'я має важливе економічне та наукове значення. Ці види $є$ цінними плодовими культурами за низкою господарських показників, а саме: відповідають вимогам сучасного плодівництва, відзначаються стійкістю до хвороб, невразливістю шкідниками, високим умістом біологічно активних речовин [1] у плодах та в інших частинах рослин, невибагливістю до грунту й агротехнікою вирощування.

У зв'язку з недостатнім вивченням адаптаційних показників видів здійснено аналіз видового складу, оцінку видів за показниками росту, генеративного розвитку, екологічними факторами. Накопичена інформація має наукове та практичне значення, що дасть можливість на теренах Кременецького ботанічного саду створити рослинну базу асортиментів плодових культур і сприяти поширенню цінних видів рослин серед садоводів нашого району.

Аналіз досліджень цієї проблеми. Вирощування рослин за межами своєї природно-географічної зони ставить їх в умови географічної невідповідності та в залежність від екологічного середовища місця зростання, що може відображатися на ефективності насіннєвого й вегетативного розмноження, визначати його здатність до самовідтворення, розвитку в умовах культури, тому комплексне вивчення цього питання актуальне для розробки наукових основ їх культивування.

Мета й завдання роботи. Відповідно до зазначеної проблеми метою досліджень було з'ясування адаптаційних показників видового різноманіття колекції та екологічної своєрідності природних об'єктів, висвітлення оцінки успішності акліматизації.

() Василюк О., Свсікова С., 2016 
Матеріали й методи дослідження. У роботі розкрито результати досліджень 2002-2016 pp. Об'єктом дослідження були нові та малопоширені плодові рослини з колекції Кременецького ботанічного саду.

Ділянки колекції інтродукованих рослин займають схил південно-західної експозиції. Грунт світло-сірий, опідзолений.

За даними гідрометеостанції, середній метеорологічний вегетаційний період у цій місцевості становить 205-209 діб. Вегетація рослин відновлюється здебільшого в першій декаді березня. Середня кількість опадів за рік 640,5 мм. Середній мінімум температури повітря сягає $-3,4^{\circ} \mathrm{C}$, абсолютний $-30,2^{\circ} \mathrm{C}$; середній максимум $+11,5^{\circ} \mathrm{C}$, абсолютний $+32,2^{\circ} \mathrm{C}$. Сума температур повітря вище $+5^{\circ} \mathrm{C}$ складає $-2770^{\circ} \mathrm{C}$.

Екологічні особливості видів охарактеризовано за Н. А. Матвєєвим [3], життєві форми - за Г. І. Серебряковим [4]. Оцінку результатів успішності акліматизації рослин проведено за методиками Н. А. Кохно, А. М. Курдюк [2].

Виклад основного матеріалу й обгрунтування отриманих результатів дослідження. Формування колекції розпочато з 2002 p. Вона нараховує на сьогодні 36 видів рослин, що належать до 26 родів, 16 родин, відділу Magnoliophyta.

Установлено, що найбільше рослин зі зростаючих малопоширених плодових та ягідних видів об'єднано в родині Rosaceae, яка нараховує дев'ять видів: Amelanhier ovalis (Medik.), Aronia melanocarpa (Michx.) Elliot., Amygdalus nana L., Mespilus germanika L., Chaenomeles speciosa (Thunb.) Lindl., Cerasus tomentosa (Thumb.) Wall., Cydonia oblonga (Thumb.) Wall. Prunus spinosa L., Sorbus aucuparia L. У родину Elaeagnaceae входить п'ять видів: Elaeagnus multiflora Thunb., Elaeagnus argentea Rursh. Nutt., Elaeagnus angustifolia L., Shepherdia argentea Pursh., Hippophae rhamnoides L. Родина Actinidiacae нараховує чотири види: Actinidia arguta (Siebold et Zucc.) Planch.ex Miq., Actinidia kolomikta (Maxim. \& Rupr.) Maxim., Actinidia poligama (Siebold et Zucc.) Maxim., Actinidia purpurea Rehd. Родину Moraceae представлено чотирма видами: Maklura pomifera (Raf.) Schneid., Morus nigra L., Morus albaL., Ficus carac L. Родина Vacciniaceae нараховує чотири види: Vaccinium uliginosum L., Vacinium corumbosum L., Vaccinium myrtilus L., Oxycoccus macrocarpus F.S.Grey. Родину Caprifoliaceae представлено двома видами - Lonicera kamtschatica (Sevast.) Pojark., Lonicera edulis Turcz. \& Freyn. Найменш численними родинами $з$ одиничними видами є Berberidaceae (Berberis vulgaris L.); Viburnaceae (Viburnum opulus L.); Cornaceae (Cornus mas L.); Corylaceae (Corylus maxima Mill.) та одна форма Corylus maxima «Purpurea». Ebenaceae (Diospuros lotus L.); Solanaceae (Lycium barbarum L.); Schizandraceae (Schisandra chinensis (Thunb.) Bail.; Rhamnaceae (Ziziphus jujube Mill.).

У процесі роботи проаналізовано еколого-біологічні особливості інтродукованих видів, дані наведено в табл. 1.

Таблиця 1

Характеристика колекції видів по еколого - біологічних особливостях

\begin{tabular}{|c|c|c|c|c|c|c|c|}
\hline \multirow{2}{*}{$\begin{array}{l}\text { № } \\
\text { 3ไII }\end{array}$} & \multirow[t]{2}{*}{ Назва родини, виду } & \multirow[b]{2}{*}{ 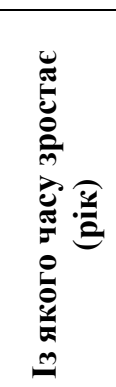 } & \multirow[b]{2}{*}{$\begin{array}{c}\text { Із } \\
\text { якого } \\
\text { року } \\
\text { прово- } \\
\text { дяться } \\
\text { дослід- } \\
\text { ження }\end{array}$} & \multirow[b]{2}{*}{ 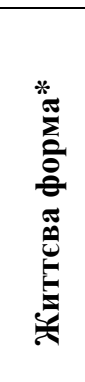 } & \multicolumn{3}{|c|}{ Екоморфа } \\
\hline & & & & & 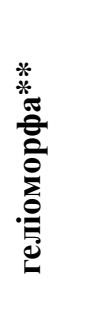 & 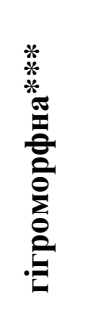 & 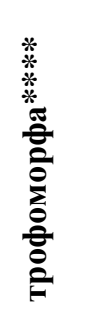 \\
\hline 1 & 2 & 3 & 4 & 5 & 6 & 7 & 8 \\
\hline & Actinidiacae Hutch. & & & & & & \\
\hline 1 & $\begin{array}{l}\text { Actinidia arguta (Siebold et Zucc.) } \\
\text { Planch.ex Miq. }\end{array}$ & 1998 & 2001 & Л. & $\mathrm{ScHe}$ & Ms & MsTr \\
\hline 2 & $\begin{array}{l}\text { Actinidia kolomikta (Maxim. \& Rupr.) } \\
\text { Maxim. }\end{array}$ & 1998 & 2001 & Л. К. & $\mathrm{ScHe}$ & Ms & MsTr \\
\hline
\end{tabular}


Продовження таблий 1

\begin{tabular}{|c|c|c|c|c|c|c|c|}
\hline 1 & 2 & 3 & 4 & 5 & 6 & 7 & 8 \\
\hline 3 & $\begin{array}{l}\text { Actinidia poligama (Siebold et Zucc.) } \\
\text { Maxim. }\end{array}$ & 1998 & 2001 & Л. & $\mathrm{ScHe}$ & Ms & MsTr \\
\hline \multirow[t]{2}{*}{4} & Actinidia purpurea Rehd. & 2004 & 2004 & Л. & $\mathrm{ScHe}$ & Ms & MsTr \\
\hline & Berbridacae Juus. & & & & & & \\
\hline \multirow[t]{2}{*}{5} & Berberis vulgaris $L$ & 1998 & 2011 & K. & $\mathrm{He}$ & Ms & $\mathrm{OgTr}$ \\
\hline & Caprifoliaceae Juus. & & & & & & \\
\hline 6 & $\begin{array}{l}\text { Lonicera kamtschatica (Sevast.) } \\
\text { Pojark. }\end{array}$ & 2007 & 2007 & K. & $\mathrm{ScHe}$ & Ms & MsTr \\
\hline \multirow[t]{2}{*}{7} & Lonicera edulis Turcz.\&Freyn & 2007 & 2007 & K. & $\mathrm{ScHe}$ & Ms & MsTr \\
\hline & Viburnacea Dumort. & & & & & & \\
\hline \multirow[t]{2}{*}{8} & Viburnum opulus L. & 2012 & 2012 & K. & $\mathrm{ScHe}$ & $\begin{array}{l}\text { Ms } \\
\mathrm{H}\end{array}$ & MsTr \\
\hline & Moraceae Gaudich. & & & & & & \\
\hline 9 & Maklura pomifera (Raf.) Schneid. & 2004 & 2004 & Д. & $\mathrm{He}$ & MsKs & $\begin{array}{l}\text { MsTr } \\
\text { OgTr }\end{array}$ \\
\hline 10 & Morus nigra L. & 2006 & 2006 & Д. & $\mathrm{He}$ & MsKs & $\begin{array}{l}\mathrm{OgTr} \\
\mathrm{Ca}\end{array}$ \\
\hline 11 & Morus alba $\mathrm{L}$. & 2002 & 2002 & Д. & $\mathrm{ScHe}$ & MsKs & $\begin{array}{l}\mathrm{OgTr} \\
\mathrm{Ca}\end{array}$ \\
\hline \multirow[t]{2}{*}{12} & Ficus carac $\mathrm{L}$. & 2010 & 2010 & Д. К & $\mathrm{He}$ & Ms & MsTr \\
\hline & Rosaceae Juus. & & & & & & \\
\hline 13 & Amelanhier ovalis (Medik.) & 1985 & 2001 & K. & $\mathrm{He}$ & MsKs & $\begin{array}{l}\mathrm{MsTr} \\
\mathrm{OgTr}\end{array}$ \\
\hline 14 & Aronia melanocarpa (Michx.) Elliot. & 1985 & 2001 & K. & $\mathrm{He}$ & Ms & MsTr \\
\hline 15 & Amygdalus nana $\mathrm{L}$. & 1985 & 2001 & K. & $\mathrm{He}$ & Ms & MsTr \\
\hline 16 & Mespilus germanika $\mathrm{L}$. & 2006 & 2006 & Д. К & $\mathrm{He}$ & Ms & MsTr \\
\hline 17 & Chaenomeles speciosa (Thunb.) Lindl. & 1998 & 2001 & K. & $\mathrm{He}$ & KsMs & MsTr \\
\hline 18 & Cerasus tomentosa (Thumb.)Wall & 1985 & 2001 & K. & $\mathrm{He}$ & KsMs & MsTr \\
\hline 19 & Cydonia oblonga (Thumb.)Wal. 1 & 2002 & 2002 & Д. К & $\mathrm{He}$ & KsMs & $\begin{array}{l}\text { OgTr } \\
\text { MsTr }\end{array}$ \\
\hline 20 & Prunus spinosa $\mathrm{L}$. & 2000 & 2001 & Д. К & $\mathrm{ScHe}$ & KsMs & $\begin{array}{l}\mathrm{MsTr} \\
\mathrm{Ca}\end{array}$ \\
\hline \multirow[t]{2}{*}{21} & Sorbus aисираria $\mathrm{L}$. & 1985 & 2010 & Д. & $\mathrm{ScHe}$ & Ms & MsTr \\
\hline & Cornaceae Dumort. & & & & & & \\
\hline \multirow[t]{2}{*}{22} & Cornus mas L. & 1998 & 2001 & Д. К & $\mathrm{ScHe}$ & $\mathrm{KsMs}$ & MsTr \\
\hline & Corylaceae Mirbet. & & & & & & \\
\hline \multirow[t]{2}{*}{23} & Corylus maxima Mill. & 2002 & 2002 & K. & $\mathrm{ScHe}$ & Ms & $\mathrm{MsTr}$ \\
\hline & Ebenaceae Gurke. & & & & & & \\
\hline \multirow[t]{2}{*}{24} & Diospuros lotus $\mathrm{L}$. & 2002 & 2002 & Д. К & $\mathrm{He}$ & Ms Ks & $\begin{array}{l}\mathrm{MsTr} \\
\mathrm{OgTr}\end{array}$ \\
\hline & Elaeagnaceae Juus & & & & & & \\
\hline 25 & Elaeagnus multiflora Thunb. & 1994 & 2001 & К. & $\mathrm{He}$ & Ks & MsTr \\
\hline 26 & Elaeagnus argentea Rursh. Nutt. & 2009 & 2009 & K. & $\mathrm{ScHe}$ & KsMs & $\begin{array}{l}\mathrm{OgTr} \\
\mathrm{MsTr}\end{array}$ \\
\hline 27 & Elaeagnus angustifolia L. & 2006 & 2006 & Д. К & $\mathrm{He}$ & KsMs & MsTr \\
\hline 28 & Shepherdia argentea Pursh & 2009 & 2009 & Д. К & $\mathrm{He}$ & $\mathrm{Ks}$ & $\begin{array}{l}\text { MsTr } \\
\text { OgTr }\end{array}$ \\
\hline \multirow[t]{2}{*}{29} & Hippophae rhamnoides L. & 2000 & 2013 & Д. К & $\mathrm{ScHe}$ & KsMs & $\begin{array}{l}\mathrm{MsTr} \\
\mathrm{Pm}\end{array}$ \\
\hline & Solanaceae Juus. & & & & & & \\
\hline 30 & Lycium barbarum L. & 2014 & 2014 & K. & $\mathrm{He}$ & KsMs & $\mathrm{OgTr}$ \\
\hline
\end{tabular}


РОЗДІЛ І. Ботаніка. 12, 2016

Закінчення таблиці 1

\begin{tabular}{|c|c|c|c|c|c|c|c|}
\hline 1 & 2 & 3 & 4 & 5 & 6 & 7 & 8 \\
\hline & Schisandraceae Blume. & & & & & & \\
\hline \multirow[t]{2}{*}{31} & Schizandra chinensis (Thunb.) Bail. & 1998 & 2001 & Л. К & $\mathrm{HeSc}$ & Ms & MsTr \\
\hline & Rhamnaceae Juus. & & & & & & \\
\hline \multirow[t]{2}{*}{32} & Ziziphus jujube Mill. & 2012 & 2012 & Д. К & $\mathrm{He}$ & Ks Ms & MsTr \\
\hline & Vacciniaceae Lindl. & & & & & & \\
\hline 33 & Vaccinium uliginosum $\mathrm{L}$. & 2004 & 2004 & K. & $\mathrm{He}$ & $\mathrm{MsH}$ & $\begin{array}{l}\text { OgTr } \\
\text { MsTr Ac }\end{array}$ \\
\hline 34 & Vacinium corumbosum $\mathrm{L}$. & 2012 & 2012 & K. & $\mathrm{ScHe}$ & $\mathrm{MsH}$ & $\begin{array}{l}\mathrm{OgTr} \\
\text { MsTr Ac }\end{array}$ \\
\hline 35 & Vaccinium myrtilus $\mathrm{L}$. & 2010 & 2011 & $\begin{array}{l}\text { K. } \\
\text { H.к }\end{array}$ & $\mathrm{ScHe}$ & Ms & MsTr \\
\hline 36 & Oxycoccus macrocarpus F. S. Grey & 2012 & 2012 & $\begin{array}{l}\text { Кущик } \\
\text { в.з. }\end{array}$ & $\mathrm{ScHe}$ & $\mathrm{H}$ & $\begin{array}{l}\text { OgTr } \\
\text { Ac }\end{array}$ \\
\hline
\end{tabular}

Примітка. *Життєва форма: Д. - дерево; К. - кущ; Л. - ліана; Н. к. - напівкущ; Кущиик в. з. - кущик вічнозелений. Геліоморфа**: геліофіт - (He), сціогеліофіт - (ScHe), геліосціофіт - (HeSc). ***Гігроморфа: ксерофіт - (Ks), мезофіт - (Ms), гігрофіт - (H), мезоксерофіт - (MsKs), ксеромезофіт - (KsMs).****Трофоморфа: оліготроф $(\mathrm{Og} T r)$, мезотроф - (MsTr), олігомезотроф - (OgMsTr), мезооліготроф - (MsOgTr); адаптовані групи рослин, ацидофіли - (Ac), (Pm) - псамофіти, базофіли $(\mathrm{Ca})$.

Аналіз колекції видів за життєвими формами [4] засвідчив, що найчисленнішими є кущові рослини - 15 видів (42\%). Друге місце за чисельністю займають види, зростання яких можливе у вигляді дерева або куща, - 10 видів (28\%). Третє місце в спектрі життєвих форм посідають дерева чотири види $(11 \%)$. Четверта група - це ліани - три види $(8 \%)$. Наступне місце поділяють види, зростання яких можливе у вигляді ліани та куща, - два види (5\%), із видами, що зростають у вигляді дерев, - два види (5 \%). Напівкущ - один вид (3\%), один вічнозелений кущик (3 \%), які, відповідно, займають останнє місце 3-поміж виявлених життєвих форм.

Дослідження екологічної структури колекції проведено за критерієм відношення рослин до води, світла та родючості грунтів [3].

За адаптивною ознакою у відсотковому співвідношенні в колекції виділяються такі екоморфи рослин (табл. 2).

Табличя 2

Екологічна структура колекції малопоширених плодових і ягідних рослин

\begin{tabular}{|c|c|c|}
\hline Основні екоморфи & $\begin{array}{c}\text { Кількість } \\
\text { видів }\end{array}$ & $\begin{array}{c}\text { Частка } \\
\text { від загальної } \\
\text { кількості } \\
\text { видів, \% }\end{array}$ \\
\hline \multicolumn{3}{|l|}{ за відношенням до світлового режиму } \\
\hline Геліофіти (Не) - облігатні світлолюби & 18 & 50 \\
\hline Факультативні світлолюби - сціогеліофіти (ScHe) & 17 & 47 \\
\hline Факультативні тіньовитривалі - геліосціофіти (HeSc) & 1 & 3 \\
\hline \multicolumn{3}{|c|}{ за відношенням до забезпечення водного режиму грунтів } \\
\hline Ксерофіти (Ks) - види посушливих місцезростань & 2 & 5 \\
\hline Мезофіти (Ms) - види помірно зволожених місць, & 15 & 42 \\
\hline Гігрофіти $(\mathrm{H})$ - види перезволожених субстратів & 1 & 3 \\
\hline Проміжні групи - мезоксерофіти (MsKs) & 5 & 14 \\
\hline ксеромезофіти (KsMs) & 10 & 28 \\
\hline мезогігрофіти(MsH) & 3 & 8 \\
\hline \multicolumn{3}{|l|}{ за відношенням до родючості грунту } \\
\hline Оліготрофи (OgTr) - види надто бідних грунтів & 5 & 14 \\
\hline $\begin{array}{l}\text { Мезотрофи (MsTr) - види, що нормально ростуть на грунтах середнього } \\
\text { рівня забезпечення }\end{array}$ & 23 & 64 \\
\hline Олігомезотроф - (OgMsTr) & 4 & 11 \\
\hline Мезооліготроф - (Ms OgTr) & 4 & 11 \\
\hline
\end{tabular}


Згідно з даними табл. 2, за геліоморфою в колекції переважають геліофіти й сціогеліофіти (97 \%) та лише один вид (3\%) геліосціофіт (Schisandra chinensis).

У складі гігроморф переважають мезофіти (42\%) і ксеромезофіти (5\%). Найменшою виявилася група рослин із гігрофітів - один вид (3\%) - Oxycoccus macrocarpus, решта - проміжні групи (50 \%).

За трофністю грунту домінують мезотрофи (64 \%), далі - оліготрофи (14\%). Рівномірно розділилися проміжні групи - олігомезотрофи та мезооліготрофи в сумі (22\%).

Далі ми провели оцінку успішності акліматизації рослин за чотирма показниками життєдіяльності: ростом (Р), генеративним розвитком (ГР), зимостійкістю (Зм), посухостійкістю (Пс), - які візуально оцінювали за п'ятибальною шкалою. При цьому застосовано коефіцієнт значущості ознаки (В), який для зимостійкості дорівнює 10 , для генеративного розвитку -5 , для посухостійкості - 3 , для росту $-2[2]$. $+\Pi c \times B$.

Ступінь акліматизації визначаємо акліматизаційним числом за формулою: $\mathrm{A}=\mathrm{P} \times \mathrm{B}+\Gamma \mathrm{P} \times \mathrm{B}+3 \mathrm{M} \times \mathrm{B}$

Таблиия 3

Оцінка успішності акліматизації малопоширених видів

\begin{tabular}{|c|c|c|c|c|c|c|c|}
\hline \multirow{3}{*}{$\begin{array}{l}\text { № } \\
\text { 3/II }\end{array}$} & \multirow{3}{*}{ Вид } & \multicolumn{4}{|c|}{ Показник життєдіяльності } & \multirow{3}{*}{$\begin{array}{c}\text { Ступінь } \\
\text { аклімати- } \\
\text { зації, } \\
\text { балів }\end{array}$} & \multirow{4}{*}{$\begin{array}{c}\text { Ступінь } \\
\text { аклімати- } \\
\text { зації } \\
\text { за значенням } \\
\text { акліматиза- } \\
\text { ційного } \\
\text { числа } \\
8\end{array}$} \\
\hline & & $\begin{array}{c}P \\
B=2\end{array}$ & $\begin{array}{l}\Gamma P \\
B=5\end{array}$ & $\begin{array}{c}3 M \\
B=10\end{array}$ & $\begin{array}{c}\Pi \mathbf{c} \\
\mathbf{B}=\mathbf{3}\end{array}$ & & \\
\hline & & \multicolumn{4}{|c|}{$\begin{array}{c}\text { середній оціночний бал за десять } \\
\text { років }\end{array}$} & & \\
\hline 1 & 2 & 3 & 4 & 5 & 6 & 7 & \\
\hline 1 & Actinidia arguta & 5 & 5 & 5 & 5 & 100 & повна \\
\hline 2 & Actinidia kolomikta & 5 & 5 & 5 & 5 & 100 & повна \\
\hline 3 & Actinidia poligama & 5 & 4 & 5 & 5 & 95 & добра \\
\hline 4 & Actinidia purpurea & 5 & 5 & 5 & 5 & 100 & повна \\
\hline 5 & Berberis vulgaris & 5 & 5 & 5 & 5 & 100 & повна \\
\hline 6 & Lonicera kamtschatica & 5 & 5 & 5 & 5 & 100 & повна \\
\hline 7 & Lonicera edulis & 5 & 5 & 5 & 5 & 100 & повна \\
\hline 8 & Viburnum opulus & 5 & 5 & 5 & 5 & 100 & повна \\
\hline 9 & Maklura pomifera. & 5 & 5 & 5 & 5 & 100 & повна \\
\hline 10 & Morus nigra & 5 & 5 & 5 & 5 & 100 & повна \\
\hline 11 & Morus alba & 5 & 5 & 5 & 5 & 100 & повна \\
\hline 12 & Ficus carica & 5 & - & 2 & 5 & - & - \\
\hline 13 & Amelanhier ovalis & 5 & 5 & 5 & 5 & 100 & повна \\
\hline 14 & Aronia melanocarpa & 5 & 5 & 5 & 5 & 100 & повна \\
\hline 15 & Amygdalus nana & 5 & 5 & 5 & 5 & 100 & повна \\
\hline 16 & Mespilus germanika & 4 & - & 5 & 5 & - & - \\
\hline 17 & Chaenomeles speciosa & 5 & 5 & 5 & 5 & 100 & повна \\
\hline 18 & Cerasus tomentosa & 5 & 5 & 5 & 5 & 100 & повна \\
\hline 19 & Cydonia oblonga & 5 & 5 & 5 & 5 & 100 & повна \\
\hline 20 & Prunus spinosa & 5 & 5 & 5 & 5 & 100 & повна \\
\hline 21 & Sorbus aucuparia & 5 & 5 & 5 & 5 & 100 & повна \\
\hline 22 & Cornus mas & 5 & 5 & 5 & 5 & 100 & повна \\
\hline 23 & Corylus maxima & 5 & 5 & 5 & 5 & 100 & повна \\
\hline 24 & Diospuros lotus & 5 & 1 & 3 & 5 & 60 & задовільна \\
\hline 25 & Elaeagnus multiflora & 5 & 5 & 5 & 5 & 100 & повна \\
\hline 26 & Elaeagnus argentea & 5 & 5 & 5 & 5 & 100 & повна \\
\hline 27 & Elaeagnus angustifolia & 5 & 4 & 4 & 5 & 85 & добра \\
\hline 28 & Schepherdia argentea & 5 & 5 & 5 & 5 & 100 & повна \\
\hline 29 & Hippophae rhamnoides & 5 & 5 & 5 & 5 & 100 & повна \\
\hline 30 & Lycium barbarum & 5 & 4 & 5 & 5 & 95 & добра \\
\hline
\end{tabular}


РОЗДІЛ І. Ботаніка. 12, 2016

Закінчення таблищі 3

\begin{tabular}{|c|l|c|c|c|c|c|c|}
\hline $\mathbf{1}$ & \multicolumn{1}{|c|}{$\mathbf{2}$} & $\mathbf{3}$ & $\mathbf{4}$ & $\mathbf{5}$ & $\mathbf{6}$ & $\mathbf{7}$ & $\mathbf{8}$ \\
\hline 31 & Schisandra chinensis & 5 & 5 & 5 & 5 & 100 & повна \\
\hline 32 & Ziziphus jujube & 5 & вег. & 4 & 5 & - & - \\
\hline 33 & Vacinium uliginosum & 3 & вег. & 4 & 4 & - & - \\
\hline 34 & Vacinium corumbosum & 4 & 4 & 5 & 4 & 90 & добра \\
\hline 35 & Vacinium myrtilus & 5 & 5 & 5 & 4 & 97 & добра \\
\hline 36 & Oxусосcus macrocarpus & 3 & 4 & 5 & 3 & 85 & добра \\
\hline
\end{tabular}

Показники росту (Р): 5 балів - (відмінний, як у природному ареалі - мають 30 видів (83\%), 4 бали - менш інтенсивний, ніж у природному ареалі, хороший - один вид (3\%,) 3 бали - помірний один вид (3\%). Не оцінювали чотири види (11\%).

Показник генеративного розвитку (ГР): 5 балів - утворює повністю схоже насіння, розмножується самосівом - 26 видів (72 \%), 4 бали - плодоношення не регулярне, утворюється мало схожого насіння, розмножується вегетативно - п'ять видів (14 \%), 1 бал - немає цвітіння, відсутнє вегетативне розмноження - один вид (3\%). Не оцінювали чотири види (11\%).

Показник зимостійкості (Зм): 5 балів - цілком виражена зимостійкість - 30 видів (83 \%), 4 бали - частково обмерзають річні пагони - один вид (3\%), 3 бали - більшість річних пагонів обмерзає один вид (3\%). Не оцінювали чотири види $(11 \%)$.

Показник посухостійкості (Пс): 5 балів - хороша посухостійкість у будь-яких умовах - 29 видів $(81 \%)$, 4 бали - відносна посухостійкість, у засуху частково скидає листя - два види (5\%), 3 бали - росте в засуху, скидає все листя - один вид (3\%). Не оцінювали чотири види $(11 \%)$.

Ступінь акліматизації в районі досліджень за значенням акліматизаційного числа становить $100 \%$ повна акліматизація у 25 видів (69 \%); 80 \% - добра акліматизація в шести видів (17\%); $40 \%$ задовільна акліматизація - один вид (3\%) (Diospuros lotus Mill.). Чотири види не оцінювалися та містять неповну інформацію: два види з родини Vacinium - менше десяти років зростання в колекції; Ficus carac L., перше плодоношення - у 2016 р., відкритий грунт; Mespilus germanika L., на період 2008 р. рослина випала, у відсотковому відношенні група цих рослин становить разом $11 \%$.

32 види в колекції в наших умовах відзначалися досить високою зимостійкістю, генеративною здатністю, збереженням габітусу. Під час роботи вони піддавалися як вегетативному, так і насіннєвому розмноженню. Характеризуються добрим приростом та здатністю регулярно квітувати й утворювати повноцінне насіння, що є доказом доброї адаптації цих рослин в умовах району дослідження.

Висновки та перспективи подалышого дослідження. Отже, проведені дослідження засвідчили, що в колекції малопоширених плодових і ягідних рослин у складі денроекзосозфлори переважає група кущів (15 видів).

Результати екологічного аналізу підтвердили переважання морозостійких видів і помірно вимогливих до вологості та середнього рівня забезпечення родючості грунту.

У результаті проведення оцінки успішності акліматизації встановлено, що 69 \% досліджуваних видів мають повну акліматизацію, 17 \% - добру й лише $3 \%$ - слабку. Це свідчить про те, що більшість представників колекції перебувають у відповідному для зростання грунтово-кліматичному середовищі, можуть поновлюватися та проявляють високу морозостійкість, стійкість до хвороб, невразливість шкідниками.

Зібрані види можна рекомендувати для вирощування в нашій місцевості.

\section{Джерела та література}

1. Василюк О. О. Інтродукція плодових та ягідних рослин в умовах Кременецького ботанічного саду / О. О. Василюк, С. С. Євсікова // Збереження та реконструкція ботанічних садів і дендропарків в умовах сталого розвитку : матеріали IV міжнар. наук. конф. (23-26 верес. 2013 р.) ; Державний дендрологічний парк «Олександрія». - Біла Церква, 2013.

2. Кохно Н. А. Теоретические основы и опыт интродукции древесных растений в Украине / Н. А. Кохно, А. М Курдюк. - Киев : Наук. думка, 1994. - С. 186.

3. Матвеев Н. М. Оптимизация системы экоморф растений А. Л. Бельгарда в целях фитоиндикации экотопа и биотопа / Н. М. Матвеев // Вісник Дніпропетровського університету. Біологія, екологія. 2003. - Т. 2. - Вип. 11. - С. 105-113.

4. Серебряков И. Г. Жизненные формы растений и их изучение / И. Г. Серебряков // Полевая геоботаника. - М. ; Л. : Наука, 1964. - Т. 3. - С. 146-208. 
Василюк Олег, Евсикова Светлана. Оценка успешности акклиматизации, характеристика биоэкологических особенностей малораспространенных плодовых и ягодных видов на базе Кременецкого ботанического сада. В статье приведены результаты анализа биоморфологической и экологической структуры дендрофлоры, которая показала преобладание морозостойких видов, что могут выращиваться в условиях умеренной влажности и среднего уровня обеспечения плодородия почвы. Произведена оценка результатов успешности акклиматизации на примере коллекции малораспространенных плодовых и ягодных видов в Кременецком ботаническом саду по показателям роста, генеративного развития и влияния экологических факторов. Результаты работы свидетельствуют о том, что большинство представителей коллекции находятся в соответствующей для роста в почвенно-климатической среде, могут обновляться и проявляют высокую морозостойкость, устойчивость к болезням, неуязвимость к вредителям. Приобретенная информация будет способствовать созданию растительной базы ассортимента плодовых и ягодных культур, распространению ценных видов растений среди садоводов нашего района.

Ключевые слова: коллекция, экоморфа, жизненная форма, степень акклиматизации, зимостойкость, генеративное развитие.

Vasilyuk Oleg, Svetlana Yevsikova. Evaluation of the Success of Acclimatization, Characteristics, Biological and Ecological Characteristics of Rare Fruit and Berry Species Based on the Krementz Botanical Gardens. The article presents the results of the analysis of biomorphological and ecological structure of dendroflora, which showed the predominance of hardy species that can be grown in conditions of moderate humidity, and the average level of ensuring of soil fertility. An estimate of the results of success of acclimatization on the example of a collection of rare fruit and berry species in Krementz Botanical garden in terms of growth, generative development and the impact of environmental factors. The results indicate that the majority of the collection are suitable for growth in soil and climatic environment that can be updated and show high frost resistance, disease resistance, invulnerability to pest. The acquired information will contribute to the creation of herbal base range of fruit and berry crops, to promote the dissemination of valuable species of plants among gardeners in our area.

Key words: Collection, ecomorph, life form, degree of acclimatization, hardiness, generative development.

Стаття надійшла до редколегії 02.09.2016 р.

УДК 581.9:574.9:581.526.45(477.4)

\section{Світлана Середницька}

\section{Екологічна характеристика Carex bohemica Schreb. (Cуреraceae) в Україні}

У статті наведено результати екологічного аналізу Carex bohemica Schreb. (Cyperaceae Juss.) флори України за екологічними шкалами Г. Елленберга та синфітоіндикаційними шкалами Я. П. Дідуха. Установлено, що осока богемська відзначається значною стенотопністю до кліматичних й едафічних факторів середовища існування, яка частково може пояснювати її рідкісність.

Ключові слова: екологічна шкала, синфітоіндикація, рідкісний вид, Carex L., Україна.

Постановка наукової проблеми та їі значення. Carex bohemica Schreb. (осока богемська) - реліктовий диз'юнктивно-ареальний субконтинентальний меридіонально-бореальний євразійський вид, який належить до найбільшого роду родини Cуреraceae Juss. [14]. Ареал цього виду охоплює значну територію Євразії, проте більш-менш суцільними є середньоєвропейська та східноазійська його частини $[4 ; 5 ; 7 ; 10 ; 15 ; 17]$.

На території України для C. bohemica характерна саме диз'юнктивна частина ареалу, де цей вид відомий у восьми адміністративних областях: Івано-Франківській, Львівській, Хмельницькій, Київській, Закарпатській, Харківській, Чернігівській і Дніпропетровській [1; 6]. Отже, в Україні розміщена лише незначна частина східоноєвропейської диз' юнкції ареалу осоки богемської у формі ізольованих локалітетів, що зумовлює іï рідкісність та є одним із головних критеріїв уключення іï до «Червоної книги України» [9]. Не менш важливим критерієм у прояві рідкісності цього виду є його доволі вузька ектопічна приуроченість і можливість займати властиву йому екологічну нішу.

Пізнання екологічних особливостей видів дає можливість оцінити ступінь екологічної амплітуди, виявити екологічний оптимум і з'ясувати деякі причини загрози для їх подальшого існування. Аналіз видів стосовно впливу на них абіотичних факторів середовища має важливе значення для встановлення заходів

(C) Середницька C., 2016 